PRACE NAUKOWE UNIWERSYTETU EKONOMICZNEGO WE WROCLAWIU

\title{
Jacek Chądzyński
}

Uniwersytet Łódzki

e-mail: jacekch@uni.lodz.pl

\section{AKTYWNOŚCI MIESZKAŃCÓW LODZI NA RZECZ OCHRONY ŚRODOWISKA RESIDENTS OF ŁÓDŹ ACTIVITIES IN FAVOUR OF ENVIRONMENTAL PROTECTION}

DOI: $10.15611 /$ pn.2017.477.04

JEL Classification: Q53, Q56, R11

Streszczenie: Tereny miejskie, ze względu na stale zwiększający się odsetek ludności je zamieszkującej oraz kumulację siedzib przedsiębiorstw przemysłowych, są szczególnie narażone na procesy degradacji środowiska. $Z$ tego względu bardzo duże znaczenie mają działania podejmowane przez władze publiczne wszystkich szczebli (od centralnego do lokalnego), które mają na celu jego ochronę. Istotne jest jednak, żeby w procesy ochrony środowiska zaangażowali się nie tylko przedstawiciele władzy i podlegających im podmiotów i instytucji, ale również mieszkańcy danej jednostki terytorialnej i prowadzący na jej obszarze swoją działalność przedsiębiorcy. Celem artykułu jest zaprezentowanie wyników badań, które zostały zrealizowane w marcu 2016 r. wśród dorosłych mieszkańców Łodzi, a które dotyczyły m.in. podejmowanych przez nich działań mających wpływ na stan i ochronę środowiska.

Słowa kluczowe: rozwój zrównoważony, ochrona środowiska, zasobooszczędne gospodarowanie, aktywność mieszkańców.

Summary: Urban areas face high risk of environment degradation due to increasing share of urban population and cumulation of industrial companies. That is why activities undertaken by authorities on all levels (from central to local) aimed at environmental protection have a significant meaning. It is very important that not only representatives of authorities and connected with them subjects and institutions, but also local population of respectives of urban units and domestic enterpreneurs engaged in environmental protection. The aim of the article is to present the results of the research carried out in March 2016 among adult inhabitants of Lodz that described undertaken activities that influenced condition and environmental protection.

Keywords: sustainable development. environmental protection, resource efficient economy, activity of inhabitants. 


\section{Wstęp}

Intensywny rozwój cywilizacyjny pociąga niestety za sobą coraz dalej idącą ingerencję w środowisko, w którym żyjemy i prowadzimy działalność. Efektem tego są coraz większe i trudniejsze do odwrócenia (niekiedy już nieodwracalne) zmiany środowiska. Świadomość konsekwencji tego stanu rzeczy spowodowała, że na znaczeniu zaczęła zyskiwać od lat 90 . XX w. koncepcja rozwoju zrównoważonego. Jej pierwsze założenia zostały zaprezentowane i przyjęte w formie 27 zasad w czerwcu 1992 r. podczas Konferencji Narodów Zjednoczonych „Środowisko i Rozwój” (tzw. Szczyt Ziemi), która odbyła się w Rio de Janeiro [Zasady... 1992]. „Zrównoważony rozwój zmierza do zapewnienia wszystkim żyjącym dzisiaj ludziom i przyszłym pokoleniom dostatecznie wysokich standardów ekologicznych, ekonomicznych i społeczno-kulturowych w granicach naturalnej wytrzymałości Ziemi, stosując zasadę sprawiedliwości wewnątrzpokoleniowej i międzypokoleniowej” [Rogall 2010, s. 85]. Oznacza to, że godzenie celów społecznych i gospodarczych z ochroną środowiska stało się absolutną koniecznością, a opracowanie i realizacja polityki ochrony środowiska jest jednym z najważniejszych zadań, jakie są stawiane przed władzami publicznymi różnych szczebli. Zgodnie z art. 13 ustawy z dnia 27 kwietnia $2001 \mathrm{r}$. Prawo ochrony środowiska [Ustawa z dnia 27 kwietnia 2001]: „Polityka ochrony środowiska to zespół działań mających na celu stworzenie warunków niezbędnych do realizacji ochrony środowiska, zgodnie z zasadą zrównoważonego rozwoju". Polityka ochrony środowiska jest prowadzona m.in. za pomocą wojewódzkich, powiatowych i gminnych programów ochrony środowiska przez samorządy terytorialne wszystkich szczebli [Ustawa z dnia 27 kwietnia 2001, art. 14, ust. 2]. Trzeba jednak podkreślić, że obecnie interpretacja pojęcia ochrony środowiska jest bardzo szeroka i uwzględnia nie tylko kwestie związane z klasycznie ujmowaną ochroną przyrody m.in. poprzez eliminację, a przynajmniej minimalizację i neutralizację wytwarzanych przez ludzi i ich gospodarki zanieczyszczeń, ale również te związane z efektywnym i oszczędnym wykorzystywaniem posiadanych zasobów naturalnych w procesach gospodarczych [Rzeńca 2016, s. 91].

Zasobooszczędne gospodarowanie to dobre i skuteczne uregulowania prawne oraz przyjmowane przez władze różnych szczebli polityki i programy, ale to przede wszystkim konkretne działania podejmowane przez konkretne podmioty. Jednym z miejsc, w których te działania powinny być podejmowane, są nasze gospodarstwa domowe. Od decyzji podejmowanych na tym najniższym szczeblu zależy bardzo dużo. Możemy jako obywatele starać się dbać o środowisko, oszczędzając zużywaną przez nas do celów prywatnych wodę, energię elektryczną czy cieplną, bądź też nic sobie nie robić z dających się już zaobserwować gołym okiem zmian. Poprzez zachowania konsumenckie związane z codziennym użytkowaniem zasobów środowiska (wody, przestrzeni, energii), wybór środka transportu czy segregację odpadów w istotnym zakresie wpływamy na kondycję środowiska [Rzeńca 2016, s. 108]. 
W ujęciu przedmiotowym podstawy proekologicznych postaw należy doszukiwać się w koncepcji homo sustinens nawiązującej do ekologii człowieka, ekologii społecznej, socjobiologii, psychologii środowiskowej oraz filozoficznych podstawach jaźni ekologicznej [Kiełczewski 2011, s. 222-223]. Podkreśla się w niej konieczność uwzględnienia całokształtu ludzkiej egzystencji i potencjału tkwiącego w jednostce ludzkiej. Bierze się pod uwagę trzy wymiary: środowisko przyrodnicze, środowisko społeczne oraz podmiotowość jednostki. Oznacza to, że oprócz potrzeb materialnych człowiek zaspokaja również potrzeby niematerialne związane ze środowiskiem przyrodniczym i społecznym. W literaturze do cech opisujących homo sustinens zalicza się:

- wolność woli i zdolność do działania odpowiedniego do podmiotowych cech jednostki;

- odpowiedzialność;

- zdolność do myślenia kompleksowego;

- umiejętność rozumowania w perspektywie długookresowej;

- zdolność do empatii, komunikacji i kooperacji;

- kreatywność;

- zdolność uczenia się;

- emocjonalność [Kośmicki 2009, s. 216-217].

Fakt, że w poszczególnych krajach, a także na poziomie międzynarodowym, podejmowane są próby kształtowania nowych wzorców zachowań konsumentów i producentów, można interpretować jako potwierdzenie narodzin homo sustinens, który uczy się budować instytucje dla zrównoważonego i trwałego rozwoju [Burchard-Dziubińska, Drzazga, Rzeńca 2014, s. 176].

Budowanie i kształtowanie świadomości ekologicznej oraz postaw obywatelskich, wzmacnianie wiedzy społeczeństwa o rozstrzygnięciach mających wpływ na środowisko i zrównoważony rozwój jest kluczowym warunkiem skutecznej polityki ekologicznej. Tutaj wyraźnie należy podkreślić olbrzymią rolę edukacji formalnej, ale również nie mniejszą rolę ,edukacji poprzez działanie” w skali lokalnej. Kluczowe dla edukacji ekologicznej są konkretne działania poprzez uświadamianie, informowanie, kształtowanie postaw oraz zapewnienie możliwości we współdecydowaniu. Wyzwaniem dla polityki miast jest kształtowanie współodpowiedzialności za środowisko, jego zasoby oraz jego jakość [Rzeńca 2016, s. 102].

\section{Podstawowe informacje dotyczące projektu badawczego}

Intencją Autora niniejszego artykułu jest odpowiedź na pytanie o powszechność działań podejmowanych przez mieszkańców dużych miast na rzecz ochrony środowiska na przykładzie Łodzi, czyli trzeciego pod względem liczby mieszkańców miasta w Polsce. Podstawą do sformułowania odpowiedzi na tak postawione pytanie są wyniki badań uzyskanych w trakcie realizacji szerszego projektu badawczego zatytułowanego „Zasobooszczędne gospodarowanie w miastach Łódzkiego Obszaru 
Metropolitalnego". Projekt ten był realizowany pomiędzy marcem a majem $2016 \mathrm{r}^{1}$ przez studentów kierunku gospodarka przestrzenna ${ }^{2} \mathrm{w}$ ramach ich ćwiczeń terenowych, a koordynowała go dr Agnieszka Rzeńca. Głównym celem projektu była identyfikacja zagrożeń środowiskowych współczesnych miast oraz aktywności mieszkańców, władz samorządowych i podmiotów administracji samorządowej na rzecz zasobooszczędnego gospodarowania.

Analizowane w artykule wyniki badań zostały zebrane techniką wywiadu kwestionariuszowego z dorosłymi mieszkańcami Łodzi (osoby w wieku 18 lat i więcej), zrealizowanego na próbie 783 osób $^{3}$. Wśród badanych łodzian dominowały osoby młode (60,4\% badanych to osoby w wieku 18-39 lat), z wykształceniem wyższym ( $46,1 \%$ badanych), zamieszkujące łódzkie bloki i wieżowce (56,4\% badanych). Niewiele więcej niż połowa z nich (51\%) posiada dzieci i dokładnie taki sam odsetek osób zadeklarował, że dochody przypadające na jednego członka rodziny mieszczą się w granicach 801-1700 zł. Pod względem statusu zawodowego największą grupę wśród badanych stanowią pracownicy zatrudnieni w podmiotach sektora prywatnego $(36,9 \%)$.

\section{Prezentacja wyników badań}

Na wstępie wywiadu badani zostali poproszeni o wskazanie najistotniejszych zagrożeń związanych ze stanem środowiska w mieście. Spośród bogatej, liczącej 16 pozycji, kafeterii możliwych odpowiedzi badani najczęściej wskazywali na brak dbałości o otoczenie ze strony samych mieszkańców (zaśmiecanie, niesprzątanie psich odchodów itp.), zanieczyszczenia powodowane przez wysokie natężenie ruchu samochodowego oraz nadmierny hałas (odpowiednio 60,4\%, 48,9\% i 43,3\% wskazań). Drugą grupę zagrożeń, pod względem ilości wskazań, stanowią zdaniem badanych: zanieczyszczenia pochodzące z palenisk indywidualnych opalanych węglem, drewnem lub, co gorsza, różnego rodzaju odpadami i śmieciami $(25,4 \%)$, zanieczyszczenia stanowiące efekt działalności przemysłu (21,2\% wskazań), nadmierne zużycie wody $(21,8 \%)$ oraz energii $(19,4 \%)$. Widać wyraźnie, że łodzianie zwracają uwagę przede wszystkim na to, co atakuje na każdym kroku ich zmysł wzroku, słuchu czy węchu, stanowiąc o dyskomforcie warunków życia. W mniejszym stopniu zwracają uwagę na zagrożenia, których bezpośrednio nie odczuwają, gdyż woda czy energia to dobra, do których mają nieograniczony dostęp, oczywiście pod warunkiem, że uiszczą za nie stosowną opłatę. Z pewnością znaczenie ma

\footnotetext{
${ }^{1}$ Samo badanie mieszkańców Łodzi odbyło się w marcu 2016 r.

2 Studenci II stopnia kierunku gospodarka przestrzenna na Wydziale Ekonomiczno-Socjologicznym Uniwersytetu Łódzkiego.

${ }^{3} \mathrm{~W}$ badaniach w ramach przywoływanego projektu brali udział również mieszkańcy 15 innych miast $\mathrm{z}$ terenu województwa łódzkiego, ale ich odpowiedzi nie zostaną uwzględnione w prezentowanych wynikach.
} 
też skala problemu ${ }^{4}$ i jego nagłośnienie w mediach. $Z$ tego względu można wysnuć przypuszczenie, że gdyby badanie zostało zrealizowane rok później, to jednym z głównych problemów wskazywanych przez mieszkańców, oprócz zanieczyszczenia pochodzącego z użytkowania samochodów, okazałoby się zanieczyszczanie powietrza będące efektem działalności przemysłu, a przede wszystkim aktywności przestarzałych indywidualnych palenisk, wykorzystujących niskiej jakości opał i różnego rodzaju odpady.

Aktywność mieszkańców, która będzie świadczyć o ich proekologicznym podejściu, może przybierać wiele form. $Z$ jednej strony mogą to być działania podejmowane przez nich w ramach własnych gospodarstw domowych, a z drugiej te, z którymi człowiek wychodzi na zewnątrz, starając się do nich przekonać innych. W ramach tej pierwszej grupy ludzie mogą się starać oszczędzać energię elektryczną i cieplną w swoich gniazdkach, kontaktach, piecach czy kaloryferach, wodę w swoich kranach czy w końcu ograniczać wytwarzanie odpadów - chociażby poprzez ich segregację.

Tabela 1. Przejawy działań proekologicznych badanych łodzian realizowanych w ramach ich gospodarstw domowych

\begin{tabular}{|l|c|}
\hline \multicolumn{1}{|c|}{ Rodzaj działań } & $\begin{array}{c}\text { Odsetek badanych podejmujących dany } \\
\text { rodzaj działania }(783=100 \%)\end{array}$ \\
\hline Oszczędzanie energii elektrycznej & 87,2 \\
\hline Oszczędzanie energii cieplnej & 66,2 \\
\hline Oszczędzanie wody & 81,2 \\
\hline Ograniczanie wytwarzania odpadów & 70,1 \\
\hline
\end{tabular}

Źródło: opracowanie własne na podstawie wyników badań.

Na podstawie wyników badań można stwierdzić, że badani mieszkańcy Łodzi w bardzo dużej części podejmują działania, które wpływają na stan środowiska. Zdecydowana większość z nich stara się ograniczać zużycie energii, wody czy wytwarzanych w ich gospodarstwach domowych odpadów (tab. 1).

Najczęściej starają się oszczędzać energię elektryczną, a najpopularniejszym tego przejawem jest deklarowane przez nich wyłączanie światła w pomieszczeniach, które w danej chwili nie są przez domowników używane. Postępuje tak prawie 90\% badanych, którzy starają się oszczędzać energię elektryczną. Dość dużym powodzeniem cieszą się również żarówki energooszczędne (prawie 66\% wskazań). Z kolei

${ }^{4}$ Łódź jest postrzegana przez mieszkańców jako miasto korków komunikacyjnych. Potwierdzają to wyniki badań. W 2016 r. miasto zajmowało piąte miejsce na świecie, a pierwsze w Europie pod względem poziomu zakorkowania komunikacyjnego [https://www.tomtom.com/en] (23.03.2017).

${ }^{5}$ Informacje o wielokrotnych przekroczeniach norm szkodliwych dla zdrowia pyłów (szczególnie PM10 i PM2.5) i unoszącym się nad polskimi miastami smogiem były na początku 2017 r. stałym punktem programów informacyjnych, a mieszkańcy Łodzi, wychodząc ze swoich domów i mieszkań, sami mogli się przekonać o skali tego niekorzystnego zjawiska. 
działania, które wymagają od badanych większych nakładów finansowych (np. zakup energooszczędnych urządzeń AGD i RTV) lub samokontroli (niepozostawianie urządzeń zasilanych prądem w trybie czuwania), są już zdecydowanie mniej popularne wśród badanych. Można również zauważyć zależność pomiędzy skłonnością do oszczędzania energii elektrycznej a wiekiem. Co do zasady (z jednym wyjątkiem w grupie najstarszych badanych), im starsze osoby, tym częściej oszczędzają. W poszczególnych grupach odsetek wskazań przedstawia się następująco:

- 18-25 lat - 83,2\% oszczędzających energię elektryczną,

- 26-39 lat-85,9\% oszczędzających,

- 40-59 lat-92,0\% deklarujących oszczędzanie,

- 60 lat i więcej - 90,8\% wszystkich wskazań w tej grupie wiekowej.

Na skłonność do oszczędzania ma również fakt posiadania dzieci. Wśród badanych, którzy je posiadają, odsetek osób starających się oszczędzać energię elektryczną wyniósł $91,2 \%$, a w grupie osób bezdzietnych $82,6 \%$.

$\mathrm{W}$ ramach oszczędzania energii cieplnej badani najczęściej decydowali się na obniżanie temperatury pomieszczeń podczas nieobecności domowników w mieszkaniu ( $68,8 \%$ osób, które udzieliły odpowiedzi na to pytanie). W następnej kolejności badani wskazywali na dokonywane przez siebie inwestycje w termomodernizację budynków - 47,1\% wskazań. Biorąc pod uwagę, że większość badanych zamieszkuje bloki i wieżowce, których właścicielami są spółdzielnie mieszkaniowe, a które mocno inwestują w takie zmiany, to aktywność w tym względzie samych badanych może być jednak niższa od deklarowanej. Na skłonność do oszczędzania energii ponownie widoczny wpływ mają: wiek badanych, fakt posiadania dzieci, a dodatkowo poziom dochodów na członka rodziny. W gronie badanych, którzy są rodzicami, odsetek oszczędzających energię cieplną wyniósł 74\%, natomiast w drugiej grupie już tylko 58,2\%. Skłonność do oszczędzania energii rośnie również wraz ze wzrostem dochodów przypadających na członka rodziny. W grupie najuboższych, których miesięczny dochód na członka rodziny nie przekracza 800 zł, odsetek wskazań wyniósł $54,1 \%$. W przypadku rodzin $\mathrm{z}$ dochodami na jedną osobę w przedziale 801-1700 zł był już wyższy i osiągnął 68,4\%. Wśród osób z dochodem mieszczącym się w przedziale 1701-4000 zł oszczędzanie ciepła deklarowało $67,9 \%$ badanych, a wśród najbogatszych (z dochodem powyżej 4000 zł na osobę) odsetek był najwyższy i wyniósł $72,2 \%$. Można więc powiedzieć, że ta sytuacja jest odzwierciedleniem głoszonej przez część społeczeństwa opinii, że oszczędzają bogaci, w ten sposób jeszcze bardziej się wzbogacając. Najwyraźniejsza jest jednak zależność pomiędzy oszczędzaniem a wiekiem badanych, co obrazuje rys. 1 .

Częściej niż energię cieplną badani oszczędzają wodę. Czyni tak $81,2 \%$ badanych. Spośród różnych form ograniczania zużycia wody najczęściej wskazywali oni na oszczędzanie wody w trakcie kąpieli, mycia rąk czy zębów oraz zmywania naczyń. Na takie kroki decyduje się $76,5 \%$ osób, które odpowiedziały na to pytanie. Dość popularną formą jest jeszcze dbanie o sprawność kranów czy toaletowych spłuczek - 67,9\% wskazań. Zdecydowanie rzadziej badanym zdarza się zainwesto- 


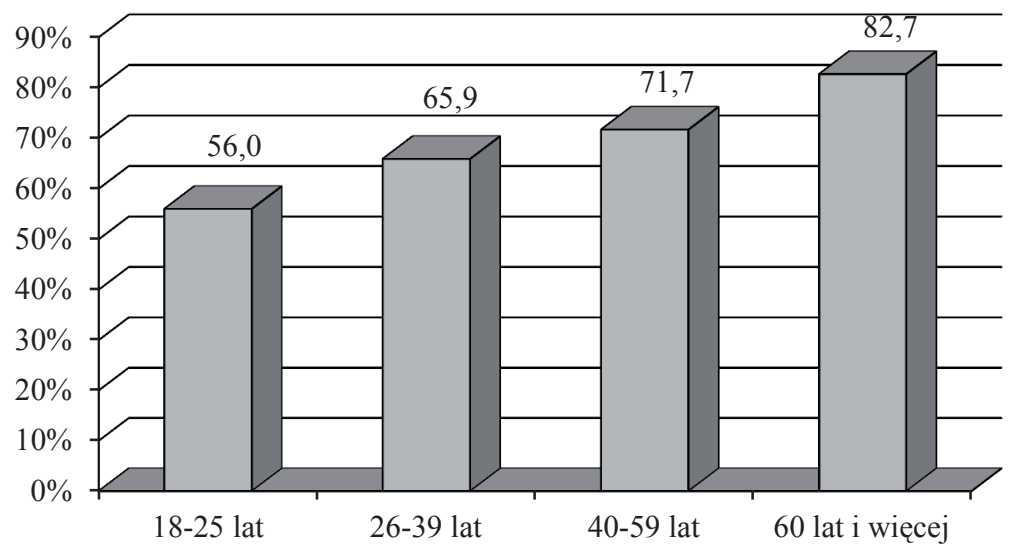

Rys. 1. Wiek badanych a skłonność do oszczędzania energii cieplnej

Źródło: opracowanie własne na podstawie wyników badań.

wać w wymianę czy usprawnienie baterii kuchennych i łazienkowych, np. poprzez instalację napowietrzaczy. Podobnie jak w poprzednich przypadkach na skłonność do oszczędzania wpływ ma przede wszystkim wiek oraz fakt posiadania przez badanych potomstwa. Dodatkowo jednak w tym przypadku można mówić o negatywnym związku pomiędzy poziomem wykształcenia a oszczędzaniem wody. Im niższy poziom wykształcenia badanych tym większy odsetek oszczędzających $\mathrm{w}$ danej grupie.

Najczęstszymi sposobami ograniczania przez badanych wytwarzania odpadów w ich gospodarstwach domowych jest segregacja, a w następnej kolejności powtórne wykorzystywanie opakowań szklanych i z tworzyw sztucznych, nawet jeśli są traktowane, tak jak w przypadku torebek foliowych, jako produkty jednorazowego użytku. Czyni tak odpowiednio 72,5\% i 62,8\% badanych. Również w przypadku ograniczania wytwarzania odpadów prym wiodą osoby najstarsze $(84,7 \%$ wszystkich osób w wieku 60 lat i więcej) oraz posiadające dzieci (76,5\% wszystkich osób w tej grupie stara się ograniczać odpady). W tym drugim przypadku można się zastanawiać, w jakim stopniu na ten fakt wpływa świadomość potrzeby dbania o środowisko, które powinno służyć jeszcze ich potomkom, a w jakim stopniu może mieć na to wpływ liczba domowników i generowanych przez nich odpadów, których trzeba się regularnie pozbywać.

Omówione dotychczas obszary i formy oszczędzania i dbania o ochronę środowiska nie wykraczały poza aktywność badanych w ramach ich gospodarstw domowych. Badani zostali jednak poproszeni również o odpowiedź na pytanie, czy angażują się w działalność na rzecz ochrony środowiska w inny sposób, wychodząc ze swoją aktywnością na zewnątrz. Takich osób jest zdecydowanie mniej, bo jedynie $20,8 \%$. Połowa z nich to osoby, które starają się działać na rzecz ochrony środowiska 
poprzez głosowanie w dotychczasowych edycjach budżetu obywatelskiego na projekty oddziałujące pozytywnie na środowisko, a co czwarty z nich deklaruje aktywność na portalach i forach społecznościowych poruszających tematykę ochrony środowiska. Szkoda, że inne formy aktywności, takie chociażby, jak uczestnictwo w konsultacjach społecznych czy uczestnictwo w działalności proekologicznych organizacji pozarządowych, mają wymiar marginalny. Na angażowanie się $\mathrm{w}$ tego typu formy aktywności decydują się w największym stopniu osoby z wykształceniem wyższym (23,8\% osób z tej grupy), a ich odsetek sukcesywnie maleje wraz z przechodzeniem do grup o coraz niższym poziomie wykształcenia. W grupie osób $\mathrm{z}$ wykształceniem podstawowym odsetek osób angażujących się w działania zmierzające do ochrony przyrody wyniósł zaledwie $8,1 \%$.

Różne są powody działań proekologicznych podejmowanych przez badanych mieszkańców Łodzi. Głównym z nich jest możliwość zaoszczędzenia pieniędzy w domowym budżecie. Na ten powód wskazuje $68,6 \%$ spośród 743 osób, które wskazały swoje powody podejmowanych działań. Co ciekawe, na tę opcję wskazywali najczęściej badani, których dochód na członka gospodarstwa domowego mieścił się w granicach 801-1700 zł, a więc wcale nie osoby o najniższych dochodach. Ta grupa uplasowała się dopiero na trzecim miejscu. Drugie miejsce zajęly osoby najlepiej uposażone, z dochodami na członka rodziny powyżej 4000 zł. Na kolejny powód - przekonanie, że podejmowane przez badanych działania przyczyniają się do poprawy stanu środowiska w mieście - zwracają uwagę głównie osoby z wykształceniem co najmniej średnim. W tej grupie osób odsetek wskazań wyniósł $50,3 \%$, a $\mathrm{w}$ grupie badanych $\mathrm{z}$ wykształceniem podstawowym i zawodowym już tylko 31,1\%. Z kolei myślenie o zasobach naturalnych i możliwości ich oszczędzenia poprzez własne działania jest najbardziej popularne wśród osób najmłodszych (na ten powód wskazuje 44,2\% badanych w wieku 18-25 lat), a jego popularność osiąga najniższy poziom wśród najstarszych $(28,9 \%$ wskazań wśród osób w wieku 60 lat i więcej). Odwrotną zależność można natomiast zaobserwować w przypadku zwracania uwagi na korzyści, jakie przynoszą podejmowane przez badanych działania dla przyszłych pokoleń - ten powód najczęściej wskazują najstarsi spośród badanych. Myślenie o przyszłych pokoleniach wskazują także częściej osoby posiadających dzieci niż bezdzietne. Nie jest to jednak istotnie duża różnica (33,6\% wskazań wśród osób z dziećmi w stosunku do 28,3\% wśród osób bezdzietnych).

Badani mieli również okazję powiedzieć, dlaczego nie podejmują opisywanych wcześniej działań (rys. 2). Głównym powodem, na który wskazują, jest zbyt duży nakład czasu i pracy (łącznie 50,5\% odpowiadających). Wydaje się, że jest to z ich strony usprawiedliwienie, które nie ma swojego realnego wymiaru, bo większość działań, o które byli pytani, wymaga przede wszystkim chęci i konsekwencji w postępowaniu, a nie czasu czy znacznego nakładu pracy. Część działań wiąże się z ponoszeniem dodatkowych kosztów (np. wymiana żarówek, urządzeń AGD i RTV, termomodernizacja budynków będących własnością badanych itp.), ale na finanse 


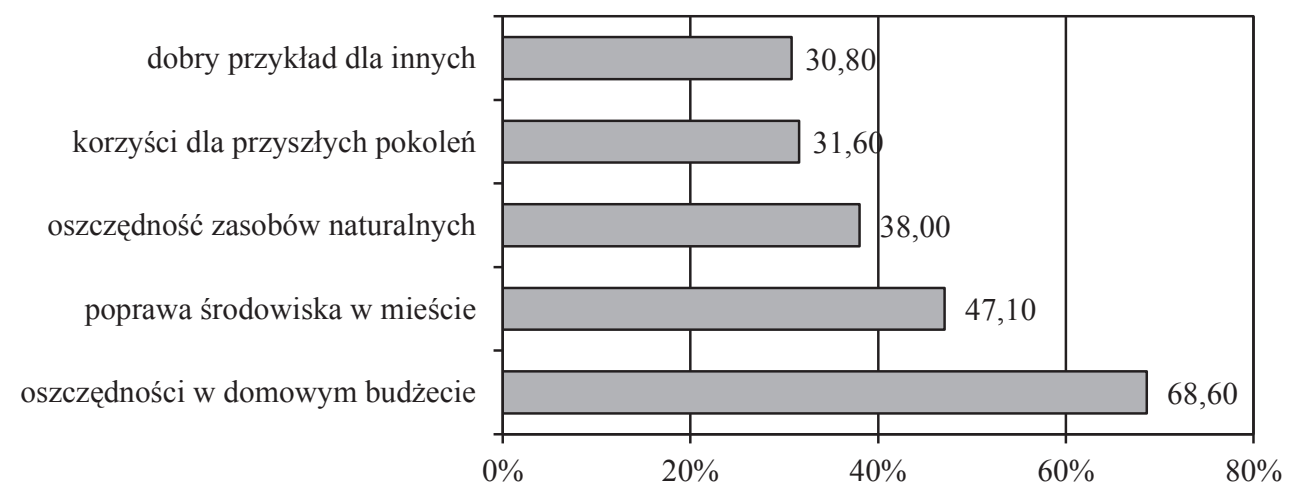

Rys. 2. Główne powody podejmowania przez badanych działań proekologicznych $(743=100 \%)$

Źródło: opracowanie własne na podstawie badań.

jako powód niepodejmowania działań proekologicznych, wskazało jedynie 13,5\% badanych. Pozostałe powody, na które wskazywali badani, to:

- brak takich działań ze strony innych mieszkańców - 28,7\%;

- brak korzyści w skali całego miasta - 20,7\%;

- płacenie podatków, które przerzuca odpowiedzialność za środowisko na państwo i samorządy - $16,4 \%$;

- tymczasowa moda - $13,4 \%$;

- korzyści wyłącznie dla producentów i dostarczycieli usług - 10,6\%.

\section{Zakończenie}

Próbując krótko podsumować zaprezentowane w artykule informacje, należy wskazać na kilka narzucających się wniosków:

1. Wyraźnie widać różnice pomiędzy działaniami mieszkańców Łodzi, które realizują oni w ramach własnych gospodarstw i najczęściej z myślą o swoich partykularnych interesach, a aktywnościami, z którymi łodzianie wychodzą poza swoje przysłowiowe „cztery kąty”. W pierwszym przypadku można mówić na dobrą sprawę o powszechności tego typu aktywności. W drugim o znacznie mniejszej popularności, a wyłączając $\mathrm{z}$ tej grupy głosowanie na projekty proekologiczne $\mathrm{w}$ ramach corocznych budżetów obywatelskich - wręcz o ich incydentalnym charakterze.

2. Można zaobserwować związek pomiędzy wiekiem i faktem posiadania dzieci a oszczędnym gospodarowaniem energią i wodą oraz ograniczaniem ilości wytwarzanych odpadów.

3. Najczęściej mamy do czynienia z negatywnym związkiem pomiędzy poziomem dochodów badanych a ich skłonnością do dbałości o środowisko wyrażaną oszczędnością wykorzystywanych przez ich gospodarstwo domowe zasobów i generowanych zanieczyszczeń. Zasada - im ktoś bogatszy, tym oszczędniejszy. 
4. Z kolei o wpływie wykształcenia na skłonność do podejmowania działań proekologicznych można mówić jedynie w kontekście działań wykraczających poza gospodarstwa domowe.

5. Nie ma natomiast wyraźnej zależności pomiędzy typem zamieszkiwanego budynku czy statusem zawodowym a skłonnością ich mieszkańców do działań wpływających na szeroko rozumianą ochronę środowiska.

6. To, co zdaniem łodzian skłania ich do podejmowania aktywności będących przedmiotem badań, to przede wszystkim pieniądze, a będąc bardziej precyzyjnym - możliwość ich zaoszczędzenia. Z kolei głównym powodem ich niepodejmowania jest tempo, w jakim współcześnie żyjemy (wieczna pogoń i brak czasu), i przekonanie o braku znaczenia indywidualnych działań dla stanu środowiska (o zbyt małej ich skali). Na to wszystko nakłada się jeszcze dość typowe dla mentalności dużej części Polaków przekonanie, że skoro inni czegoś nie robią, to po co ja mam to robić.

7. Wydaje się więc, że dla zwiększenia skali indywidualnych działań związanych z zasobooszczędnym gospodarowaniem ważne jest z jednej strony wzmocnienie w mieszkańcach przekonania, że takie działania będą im się rzeczywiście opłacały (np. poprzez system ulg, na który wskazują sami badani). $Z$ drugiej powinno to być poparte permanentną (na każdym etapie życia człowieka) edukacją proekologiczną i uświadamianiem, że powszechność działań indywidualnych może dać efekt skali i wpłynąć na jakość środowiska, w którym żyją oni sami, a w przyszłości chciałyby żyć ich dzieci, wnuki i kolejne pokolenia ich potomków.

\section{Literatura}

Burchard-Dziubińska M., Drzazga D., Rzeńca A., 2014, Zrównoważony rozwój - naturalny wybór, Wydawnictwo Uniwersytetu Łódzkiego, Łódź.

https://www.tomtom.com/en_gb/trafficindex/list?citySize=ALL-\&continent=ALL\&country=ALL (23.03.2017).

Kiełczewski D., 2011, Homo oeconomicus i homo sustinens jako wyzwania ekonomii zrównoważonego rozwoju, [w:] Poskrobko B. (red.), Teoretyczne aspekty ekonomii zrównoważonego rozwoju, Wydawnictwo Wyższej Szkoły Ekonomicznej w Białymstoku, Białystok.

Kośmicki E., 2009, Główne zagadnienia ekologizacji społeczeństwa i gospodarki, Wydawnictwo Ekopress, Białystok.

Rogall H., 2010, Ekonomia zrównoważonego rozwoju. Teoria i praktyka, Zysk i S-ka, Poznań.

Rzeńca A., 2016, Polityka ekologiczna miast, [w:] Rzeńca A. (red.), EkoMiasto \# Środowisko. Zrównoważony, inteligentny i partycypacyjny rozwój miasta, Wydawnictwo Uniwersytetu Łódzkiego, Łódź.

Rzeńca A., 2016, Wyzwania i dylematy polityki miejskiej w obliczu kryzysu ekologicznego, Studia Ekonomiczne Regionu Łódzkiego, nr XXI.

Ustawa z dnia 27 kwietnia 2001 r. Prawo ochrony środowiska, tekst jedn. Dz.U. z 2001, nr 62 poz. 627.

Zasady ogólnych praw i obowiązków. Deklaracja z Rio de Janeiro w sprawie środowiska i rozwoju, http://www.ko.poznan.pl/pub/ftp/Edukacja_zrownowazonego_rozwoju/DEKLARACJA_Z_ RIO_1992.pdf(12.11.2016). 